\title{
Private Label Distribution: Lessening Competition Under the Robinson-Patman Act
}

Today many trademarked commodities are available at considerably lower prices without the trademark or with some less well known trademark. Known as private label distribution, ${ }^{1}$ this practice of distributing a physically identical product under more than one label may be illegal under the Robinson-Patman Act's proscription of the sale of goods of "like grade and quality" at differing prices where such sale may "Iessen competition."'2 Recently the Fifth Circuit, on remand from a divided Supreme Court, prohibited such a distribution of milk in Borden Co. v. $F T C^{3}$ where an injury to competition would be likely.

I In practice, a manufacturer who sells his well-known brand item without the brand label may do so in one of three ways. He may sell the item without any label, leaving it to the wholesale customer to affix the wholesaler's private label; he may affix the wholesaler's private label to the item before shipment; or he may affix his own private label. All of these marketing methods will be called "private label distribution," including the first, which is actually unlabeled distribution from the viewpoint of the manufacturer.

2 Robinson-Patman Act, 15 U.S.G. § 13(a) (1964). Specifically, the statute provides: "It shall be unlawful for any person engaged in commerce . . . to discriminate in price between different purchases of commodities of like grade and quality . . . where the effect of such discrimination may be substantially to lessen competition or tend to create a monopoly in any line of commerce, or to injure, destroy, or prevent competition with any person who either grants or knowingly receives the benefit of such discrimination, or with customers of either of them: Provided, That nothing herein contained shall prevent differentials which make only due allowance for differences in the cost of manufacture, sale, or delivery resulting from the differing methods or quantities in which such commodities are to such purchasers sold or delivered."

3 Borden Co. v. FTC, 339 F.2d 133 (5th Cir. 1964), rev'd, 383 U.S. 637 (1966), on remand, 381 F.2d 175 (1967).

The Borden case attracted considerable attention during its judicial history. In a complaint filed before the FTC, Borden was charged with violating section 2(a) of the Robinson-Patman Act. Borden defended on three grounds: (I) due to demonstrated consumer preference, the two brands 'of milk were not of "like grade and quality"; (2) there was no "lessening of competition"; and (3) the difference in price was cost justified. The hearing examiner resolved the first issue against Borden but found cost justification and no competitive injury. Reversing, the FTC held against Borden on all issues. On appeal the Fifth Circuit overruled the Commission, holding that the two brands of milk were not of "like grade and quality" because consumers preferred the Borden trademark. This decision induced Jordan to mention the case in his article on dual distribution. Jordan, Robinson-Patman Aspects of Dual Distribution by Brand of Consumer Goods, 50 CORNELI. L.Q. 394, 406 (1965). Criticizing the Commission for overlooking the economic difference between the two brands of milk, Jordan maintained that the court's ruling was also 
The Borden case illustrates the more general problem the courts have confronted when interpreting the Robinson-Patman Act: can the statute promote the economic goals of efficiency and proper alloçation of resources without becoming a dead letter? After briefly describing the economics of private label distribution, this comment will consider the interpretations which the "lessening competition" language of the Robinson-Patman Act could reasonably support and the result finally reached in Borden. In conclusion, a heretofore unexplored rationale for Robinson-Patman Act interpretation will be suggested and analyzed in relation to the Borden decision.

\section{I}

Private label distribution enables a manufacturer to serve both the economy-minded customer and the quality-conscious customer. While the former, economy-minded customer is primarily interested in obtaining a given item at the least expensive price, the latter is willing to pay more to obtain a well-known and well-advertised brand of proven quality. Of course, consumers are both economy and quality minded; the difference is one of degree. An unknown private brand cannot normally compete with an established trademarked brand unless it is lower priced since consumers tend to prefer the known "quality" item. According to economists, therefore, at any given price the aggregate demand for the trademarked good is greater than the aggregate demand for the unbranded or private label good. Expressed in legal termi-

incorrect because retail consumer preferences should not be the measure of quality at the wholesale level.

The Fifth Circuit holding also elicited a flurry of casenotes concerning the "like grade and quality" test. These notes were in no sense in agreement. While 6 B.C. IND. \& CoM. L. REv. 966 (1965) raised some of the problems involved in defining "like grade and quality" according to consumer preferences, $10 \mathrm{VIIL}$. L. REv. 601, 606 (1965) indicted the Fifth Circuit for "discarding case precedent and reversing legislative policy" in its rejection of the physical identity test. By contrast, 40 NOTre DAME LAw. 468, 471-72 (1965) accused the FTC of making its own job easy by adopting a physical identity test, a position contradictory to its use of a consumer preference test under section 2(b)'s "meeting competition" provision.

The controversial Fifth Circuit holding was reversed by the Supreme Court which finally clarified the law, holding that a difference in consumer preference alone does not establish differing quality. This result was extensively reviewed in Note, 55 CAL. L. REv. 535 (1967), much of which is now obsolete, since its analysis of the effect of an absolute prohibition of dual distribution was based on the author's belief that the injury issue would be resolved against Borden. "[O]nce the Commission finds a price differential and injury in the form of reduced sales on the part of competitors, the causal connection between the two automatically is established." Id. at 542. Although this prediction proved incorrect, the author should hardly be indicted for his error, since his view seems to have been widely shared by the bar despite contrary warnings in Anheuser-Busch, Inc. v. FTC, 289 F.2d 835, 839-40 (7th Cir. 1961). 
nology, the consumer preference for the trademarked item is greater than the consumer preference for the privately labeled item. It should be remembered that consumer preference is an aggregate concept which refers not to any given consumer, but to the totality of all consumers.

In order for one commodity to be competitive with another, it must be priced so that the average consumer is indifferent toward the two goods. ${ }^{4}$ Thus, if private label items are to be competitive, they must be priced at a discount below the trademark price, the discount being determined by the differing consumer preferences for the items. Moreover, the "dual distribution" of both advertised trademark articles and unadvertised private label goods allows the cost of advertising to be passed on to those who are influenced by advertising rather than to the general consuming public. The consumer has the alternative of buying private label goods rather than the higher priced advertised product, whose price to some degree reflects the costs of advertising.

This differential consumer preference problem troubled the Borden Milk Company. In order to market its private label milk, it offered customers substantial reductions in price over the price of Borden label milk, even though both brands of milk were chemically identical. Viewed by the FTG as a violation of the Robinson-Patman Act, this two price system presented the courts with the problem of whether consumer preference should be considered under section 2(a) of the Robinson-Patman Act. In order to resolve this question, one should understand the motives of the company and the economic effects of private label distribution.

The economics of differentiated products 5 explains why the manufacturer of a trademarked product is willing to sell the same product without his trademark at a substantially lower price. First, he cannot sell more of his product under the trademark label without decreasing its price since, at any given price, the amount he can sell is limited by the demand for that product. ${ }^{6}$ While the manufacturer in the homogeneous market is negligibly influenced by the price depressing effect

4 If the average consumer were not indifferent, one of the items would "move" better than the other. Manufacturers would shift to producing more of the "moving" commodity and less of the other item. This supply change would result in a price change and would continue until the equilibrium, or indifference, stage was reached.

5 A differentiated product is any product in which the output of one manufacturer is distinguished in the mind of the consumer from those of other producers, due to style, brand, quality, or similar considerations. Pioneer work in economic analysis in this field was done by Edward Chamberlin. See E. Chamberin, The Theory of Monopolistic CoMpeTrion (8th ed. 1965).

6 At a given demand, the amount which can be sold at any given price is fixed. As output increases, price must decrease in order to induce consumers to buy more. 
of his final units of output, the manufacturer of a product that is differentiated must be sensitive to the price depressing effect of each additional unit he sells. Each extra unit sold by the differentiated product firm decreases the price it can charge for all prior units. ${ }^{7}$ Like any increase in cost, this effect results in less output by the differentiated product firm, as compared with the producer of a homogeneous product.

The decrease in output resulting from this depressing effect is itself a social cost of differentiated products. In addition, product differentiation results in the inefficient use of resources since no matter what the scale of the producer's plant, ${ }^{8}$ the depressing effect is always present. The manufacturer of the differentiated product will stop short of the level of output justified by production costs alone since he must also consider the depressing effect as a cost of continued operation. Therefore capital equipment will not be utilized as fully as if the depressing effect were not present. This result cannot be escaped by decreasing the investment in capital equipment. Since, at any scale, the producer determines output by considering both the production costs of additional output and the depressing effect, optimum use of capital equipment will never be achieved. ${ }^{9}$

While escape from the inefficient use of resources is possible, ${ }^{10}$ most economists have apparently ignored private label distribution

7 A. Alchian \& W. Allen, University Economics 108-12 (2d ed. 1967).

8 "Plant" as used here includes distribution network and other "overhead" assets as well as capital equipment.

( A geometric proof of this proposition is commonly offered: The differentiated product firm faces a negatively sloped demand curve $(D)$. Efficiency conditions are defined as the point where $D$ is tangent to $A C$ (the average cost curve) at its lowest point. But where $D$ is negatively sloped it cannot be drawn tangent to the lowest (zero sloped) point of $A C$. (The reader is invited to try.)

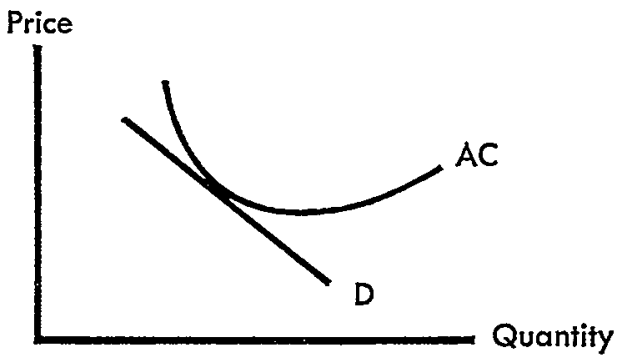

For a fuller exposition of this proof, see G. BAcH, Economics 431-33 (5th ed. 1966).

10 Some economists have concluded that the problem really does not exist. See, e.g., A. Alchian \& W. Allen, UnIversity Economics 187-88 (2d ed. 1967); Demsetz, The Nature of Equilibrium in Monopolistic Competition, 67 J. PoL. Econ. 21 (1959). But the theory that at least potential resource inefficiency exists in a differentiated product market remains the accepted view of most economists. 
as one such avenue. A manufacturer worried about the depressing effect of additional output on his trademarked product may produce the optimal output for his plant and sell the excess on a private label basis. Indeed, he may even be able to increase the scale of his plant, thus taking advantage of previously unavailable economies of scale. The advantage to the producer of private label goods is the opportunity to increase production without glutting the market with his trademarked commodity; the advantage to the alert consumer is a premium product at a thrifty price; and the advantage to the society is variety without wasted resources.

\section{II}

Although private label distribution serves a valuable economic function, the language of the Robinson-Patman Act, ambiguous on its face, could be interpreted as outlawing this practice. Section 2(a) ${ }^{11}$ prohibits any practice which satisfies three criteria. First, "price discrimination" must be practiced. Second, this discrimination must occur between different purchasers of a commodity of "like grade and quality." Finally, the effect of this discrimination must be to "lessen competition." Two statutory defenses are also available: any cost differential justifies an equal price differential, ${ }^{12}$ and a defendant may meet an equally low price of a competitor. ${ }^{13}$

While courts have given some content to these provisions, many ambiguities remain in defining the statutory terms. ${ }^{14}$ The Supreme Court has authoritatively defined "price discrimination" as meaning any price differential. ${ }^{15}$ In doing so it rejected an alternative economic definition which would have incorporated considerations of cost and consumer preferences. The Court reasoned that the Congress had intended to include such criteria within the other provisions of the act.

11 See Robinson-Patman Act, I5 U.S.C. \$ 13(a) (1964).

12 Id., especially the proviso. See United States v. Borden Co., 370 U.S. 460 (1962); Reid v. Harper \& Bros., 235 F.2d 420 (2d Cir. 1956).

On the cost justification defense, see Elman, The Robinson-Patman Act and Antitrust Policy: A Time For Reappraisal, 42 Wasfr. L. Rev. 1, 14-16 (1966); Rowe, Cost Justification of Price Differentials Under the Robinson-Patman Act, 59 Coc. L. REv. 584 (1959).

13 Section 2(b) of the Robinson-Patman Act, 15 U.S.C. \$ 13(b) (1964), sets up a general defense that nothing "shall prevent a seller rebutting the prima-facie case thus made by showing that his lower price... was made in good faith to meet an equally low price of a competitor."

14 The courts have commented on the lack of clarity in the Robinson-Patman Act. Automatic Canteen Co. v. FTC, 346 U.S. 61, 65 (1953); Ruberoid Co. v. FTC, 189 F.2d 893, 894.95 (2d Cir. 1951). See also Adelman, The Consistency of the Robinson-Patman Act, 6 StAN. L. Rev. 3 (1953).

16 FTC v. Anheuser-Busch, Inc., 363 U.S. 536 (1960). 
"Lessening of competition," for example, would be a superfluous provision if economic considerations had been read into the definition of "price discrimination." 16

On the other hand, the "commodities of like grade and quality" provision has not been as well defined. ${ }^{17}$ In the past the courts have apparently approved a physical identity test, ${ }^{18}$ a functional interchangeability test, ${ }^{19}$ and a consumer preference test, ${ }^{20}$ three standards that are not necessarily consistent. Illustrating the potential inconsistency, private label distribution falls under the Robinson-Patman Act if either the physical identity test or the functional interchangeability test is applied, but if the standard is consumer preferences, private label distribution is beyond the scope of the statute. It is therefore not surprising that when private label distribution was challenged in Borden an important aspect of the case concerned whether the two brands of milk were "commodities of like grade and quality." 21

Probably the most difficult provision of section 2(a) to apply to individual factual settings is the "lessening competition" criterion. Actual injury to competition need not be shown; a possibility of such injury will suffice. ${ }^{22}$ While an injury to competition has been automatically inferred from the very nature of the price differential, ${ }^{23}$ such an inference has never been made concerning injury to the seller's competitors (primary line injury). ${ }^{24}$ The "lessening competition" test also involves proof problems which have only been partially explored ${ }^{25}$ in

16 Id. at $550-51$.

17 The issue has been touched upon in a few cases. See Atlanta Trading Corp. v. FTC, 258 F.2d 365 (2d Cir. 1958); E. B. Muller \& Co. v. FTC, 142 F.2d 511, 518 (6th Cir. 1944); McWhirter v. Monroe Calculating Mach. Co., 76 F. Supp. 456, 460 (W.D. Mo. 1948); notes $18-20$ infra.

18 Moog Indus., Inc. v. FTC, 238 F.2d 43, 49-50 (8th Cir. 1956); Bruce's Juices, Inc. v. American Can Co., 87 F. Supp. 985 (S.D. Fla. 1949), aff'd, 187 F.2d 919, modified, 190 F.2d 73 (5th Cir. 1951); Midland Oil Co. v. Sinclair Refining Co., 41 F. Supp. 436, 438-39 (N.D. III. 1941).

19 See cases cited note 18 supra. For an analysis under the Sherman Act, see Times Picayune Publishing Co. v. United States, 345 U.S. 594 (1953).

20 Bruce's Juices, Inc. v. American Gan Co., 87 F. Supp. 985 (S.D. Fla. 1949), aff'd, 187 F.2d 919, modified, 190 F.2d 73 (5th Cir. 1951).

21 The original Fifth Gircuit decision and the Supreme Court decision in Borden were directed to this issue. Indeed, it was not until remand from the Supreme Court that the Fifth Circuit even considered other provisions of the Act.

22 FTC v. Morton Salt Co., 334 U.S. 37, 46 (1948).

$23 \mathrm{Id}$. at 47.

24 The courts specifically refused to draw such an inference in Anheuser-Busch, Inc. v. FTC, 289 F.2d 835 (7th Cir. 1961) and Shore Gas \& Oil Co. v. Humble Oil \& Refining Co., 224 F. Supp. 922 (D.N.J. 1963).

25 The greatest difficulty has resulted from the "automatic inference" of injury in FTC v. Morton Salt Co. 334 U.S. 37 (1948). On the facts of that case the Supreme Court 
the literature and on which the reach of the precedents is unclear. More significantly, no court has ever directly answered the central question of statutory interpretation inherent in the "lessening competition" phrase: what, precisely, is meant by the word "competition?"26

Viewed against this statutory backdrop, private label distribution clearly constitutes "price discrimination" since it involves a difference in price. But whether physically identical goods with different labels qualified as "commodities of like grade and quality" was unclear until the Borden case so held.

Many views of the proper reading of the "like commodities" clause have been expressed. ${ }^{27} \mathrm{Mr}$. F. Rowe ${ }^{28}$ has been a leading proponent of drastically narrowing the scope of the Robinson-Patman Act by including consumer preferences within that provision, thus "rationalizing" the act by making its language responsive to operations of the market. In the market, price is determined by the interaction of supply and demand. By recognizing variations in cost as justifiable grounds for price differences, the Robinson-Patman Act explicitly incorporates supply considerations into its schema. By accommodating consumer preferences within the "like grade and quality" provision, Rowe hoped also to read the demand factor into the act.

Although Rowe's position was supported by the minority of the Attorney General's commission on the antitrust laws, ${ }^{29}$ by the initial Fifth Gircuit decision in Borden, ${ }^{30}$ and by Mr. Justice Stewart's dissent

found the evidence sufficient to support a finding of injury. This led some commentators to conclude that injury would always be inferred automatically once any price differential was shown. See, e.g., Rowe, Price Differentials \& Product Differentiation: The Issues Under the Robinson-Patman Act, 66 YALE L.J. 1, 18-21 (1956).

But in Morton Salt, the facts of the case supported the Supreme Court's finding of an injury to competition. In addition, the Court was very aware of the fact that it was dealing with a secondary line case (334 U.S. at 51-52). It therefore seems doubtful that Morton Salt should be read to have the sweeping effect attributed to it by Rowe.

26 For the definition of "competition" as used in other contexts, see text accompanying note 61 infra.

27 C. Austin, Price Discrimination and Related Problems Under The RobinsonPatman act 38-40 (2d rev. ed. 1959); S. Oppenheim, Unfatr Trade Practices 1031-38 (1950); Cassady \& Grether, The Proper Interpretation of "Like Grade and Quality" within the meaning of section 2(a) of the Robinson-Patman Act, 30 S. CAL. L. REv. 241 (1957); Jordan, Robinson-Patman Act Aspects of Dual Distribution By Brand of Consumer Goods, 50 CORNell L.Q. 394 (1965); Mason, Discrimination in Price Between Different Purchasers of Commodities of Like Grade, Quality, and Popularity, ABA ANTIrrusT SEction Procerdings 82 (1953); Comment, Like Grade \& Quality: Emergence of the Commercial Standard, 26 Oнг ST. L.J. 294 (1965).

28 Rowe, Price Differentials and Product Differentiation: The Issues Under The Robinson-Patman Act, 66 YALE L.J. 1, $45-48$ (1956).

29 U.S. Attorney General's National Commitree To Study The ANtrtrust Laws, REPORT 158 (1955).

30 "In determining whether products are of like grade and quality, consideration should 
in the Supreme Court,"31 a majority of the Court adopted a "physical identity" test of "like grade and quality,"32 at least in the extreme case of physically identical goods differentiated only by brand. If the Rowe position had been adopted, once two goods were found to differ in consumer preference in any degree, the relative prices of the two would have been wholly beyond the legal constraints imposed by Robinson-Patman. This differs considerably from the cost defense which permits only a proportional price differential. ${ }^{33}$ Thus, recognition of consumer preferences under the "like grade and quality" provision would have had a much more profound effect, limiting the "jurisdictional" scope of the statute.

In rejecting the Rowe position, the Supreme Court recognized that within some range most commodities are interchangeable. ${ }^{34}$ It prevented sellers from accomplishing with a near substitute-in the Borden case a substitute distinguishable only by brand name-the discriminatory treatment of buyers which the Robinson-Patman Act forbids. By pricing the private label brand well below the market price a manufacturer could also drive out lower priced competitors of his trademarked product. Furthermore, sales by other "quality" product suppliers might be seriously curtailed since if the private brand is sufficiently inexpensive most consumers will take this "cheap" substitute rather than the "quality" item.

Fear of the emasculation of the Robinson-Patman Act may have originally led the FTC in Borden to reject the consumer preferences concept under section 2(a), even though that agency recognizes the usefulness of the consumer preferences concept under another provision of the Robinson-Patman Act, section 2(b) ${ }^{35}$ This divergent treatment seems justifiable since recognizing differences in consumer preferences under section 2(b), the meeting competition section, would not fore-

be given to all commercially significant distinctions which affect market value, whether they be physical or promotional." Borden Co. v. FTC, 339 F.2d 113, 137 (5th Cir. 1964).

31 "[T] he Court ignores a most relevant aspect of the inquiry into the question of 'like grade and quality' under section 2(a): whether the products are different in the eyes of the consumer." Borden Co. v. FTC, 383 U.S. 637, 648 (1966).

32 To be more exact, the Supreme Court held the fact of physical identity alone would make commodities alike: hence, physical identity is sufficient, but may not be necessary, to justify a finding of like grade and quality. The issue of where to draw the line between "commodities of like grade and quality" when some actual physical difference is present remains an open one.

33 See authorities cited note 12 supra.

34 Economists "measure" substitutability by a concept called cross-elasticity of demand. Elasticity is the relative responsiveness of a change in quantity to a change in price.

35 See Standard Oil Co., 49 F.T.C. 923 (1953); Minneapolis-Honeywell Regulator Co., 44 F.T.C. 351 (1948). 
close the issue of injury as it would under the "like grade and quality" provision of section 2(a).

But the FTC was not content in Borden with its exclusion of consumer preferences under the "like grade and quality" provision; rather, it maintained that consumer preferences should not be considered at all under 2(a), ${ }^{36}$ even as a justification for differing prices which do not "lessen competition." Thus, except where price differences were completely cost justified, the FTC's reading of the Robinson-Patman Act would render illegal per se the widespread marketing technique of private label distribution. ${ }^{37}$ As explained earlier, this would result in less than optimal utilization of the resources of the society. ${ }^{38}$ In addition, it would invite sellers to make slight physical changes in their quality products so they could distribute a physically different product under a private label, perhaps resulting in deliberate product adulteration.

While the FTC may have hoped its interpretation would discourage larger manufacturers from continuing their "economy" label production, thus assisting small businessmen, this result is by no means certain. "Quality" manufacturers' brands such as Borden's Milk already compete with distributors' brands. If the law were to forbid the manufacturers from selling both trademarked and non-trademarked goods, he might choose to sell only on a private label basis, selling his copyrighted trademark to a distributor. Thus, the FTG position could encourage distributor trademarking while discouraging manufacturer trademarking. Such an effect would aid large retailers with their own nationally established brands while depriving small retailers of some wellknown manufacturers' brands. This result would hardly aid the small businessman.

Fortunately, on remand the Fifth Circuit rejected the FTC's position on competitive injury, refusing to infer such injury automatically. Instead the court considered whether, in light of consumer preferences, the price differential was likely to result in the competitive injury

36 See Borden Co. v. FTC, 381 F.2d 175, 181 (5th Cir. 1967), where the court points out the Commission's total failure to consider, or even mention, the commercial significance of the consumer appeal of the Borden label.

37 The FTC might object to the categorization of its reading of Robinson-Patman as per se illegality, since at no time did it argue that the cost defense was unavailable to Borden. But the cost defense is inadequate to deal with a pricing differential due to differing consumer preferences since where the product is differentiated, price is influenced not only by cost but also by consumer preferences. It would be a most unusual instance (known to the economist as long run equilibrium) in which the market price differential between two commodities exactly equals the cost difference between them.

38 See text accompanying note 9 infra. 
proscribed by the statute. ${ }^{39}$ It found no injury to competition in either the primary line (injury to Borden's competitors) or the secondary line (injury to buyers). The court held that: "[C]ompetitive injury [in the secondary line] is not caused by a price differential which measures only the economic value of a premium label as compared to a private label." 40 Similarly, in the primary line, the Fifth Circuit refused to infer a competitive injury unless the FTC proved that the price differential exceeded the difference in economic value of the two articles. ${ }^{41}$

Thus, by introducing an economic causal step into the section 2(a) "lessening of competition" provision, the Fifth Circuit focused attention on differences in consumer preferences. Future RobinsonPatman price discrimination cases will be unsuccessful unless the FTG or a private plaintiff can prove that the prices of two near substitute commodities do not accurately reflect the consumer preferences between them. ${ }^{42}$

To understand the implications of this decision, it is useful to devise an analytical concept, "mispricing." As used here, "mispricing" means the maintenance of a price above or below that which would prevail in the free market, measured in relation to some other commodity. So long as the price differential between two products corresponds to the difference in consumer preferences, that is, so long as there is no mispricing, the dictates of the Robinson-Patman Act are satisfied. ${ }^{43}$

An economic analysis of mispricing illuminates the policy reasons behind the Borden decision. If mispricing occurs, consumers taken as a whole tend to purchase the item which is "underpriced" in terms of their preferences, passing up the "overpriced" substitute. Since there is a lower than optimal sales volume in the overpriced brand and a lower than optimal price in the underpriced brand, the producer re-

39 Borden Co. v. FTC, 381 F.2d 175, 180-81 (5th Cir. 1967). In distinguishing the Morton Salt case, the Fifth Circuit pointed out that Morton had "used a standard volume discount to create a price differential whose effects are so different from those involved there as to make that decision inapposite to the one before us." Id. at 181.

40 Borden Co. v. FTC, 381 F.2d 175, 180 (5th Cir. 1967).

41 " $[\mathrm{I}]$ njury proved in the primary line, if any, is not the effect of the price difference in issue." $I d$. at 180.

42 The court pointed out the "absence of the necessary causal relationship between the difference in prices and the alleged competitive injury. ... [N]one of the evidence ... relates to the price difference between the milks marketed by Borden. . . . [C]ompetitive injury is not caused by a price differential which measures only the economic value of a premium Iabel as compared to a private label." Id. at 180.

43 This sentence is really a paraphrase of the exact words of the court: "[C]ompetitive injury is not caused by a price differential which measures only the economic value of a premium label as compared to a private label." Id. at 180 . 
ceives less than maximum profits on both items.44 Why would any producer choose to engage in such a foolish policy? The courts and Congress have hypothesized two possible reasons. First, he may give lower prices to one or a few buyers, ${ }^{45}$ either because he favors them or because they have large purchasing power with which to coerce such concessions. This injures competition in the secondary line because the buyers who do not receive the price reductions may be unable to compete successfully with the favored purchasers. Second, a producer may predatorily cut his prices, using one brand as a loss item to drive out his own competitors. ${ }^{46}$ In this way competition is hurt in the primary line. By outlawing mispricing, the Fifth Circuit read the statute to forbid both abuses.

The mispricing concept also contains significant proof problems. The Fifth Circuit cast the burden of proving mispricing onto the FTC rather than merely permitting the defense to bring forward evidence to disprove it. ${ }^{47}$ This approach seems more reasonable than an initial presumption that mispricing exists in all cases, ${ }^{48}$ since mispricing is economically foolish from the the seller's point of view. Accordingly, if secondary line injury is alleged, a presumption of mispricing should not arise until proof has been brought forward evidencing a refusal to sell both product lines to all customers. ${ }^{49}$ If the lower price is available to all customers, it would hardly seem fair to presume a customer was injured when he has himself chosen to pay the higher price. ${ }^{50}$ As

44 He will be giving up profits in the underpriced item in the form of prices lower than those he could be getting and in the overpriced item in the form of lower than optimal output. Stated differently, his price-sales volume mix will be other than the profit maximizing mix.

45 The Court in Morton Salt, 334 U.S. at 43-44, quotes from the House Committee Report, H.R. REP. No. 2287, 74th Cong., 2d. Sess. 7 (1936): "[The Robinson-Patman Act's] purpose was to limit 'the use of quantity price differentials to the sphere of actual cost differences. Otherwise, ... such differentials would become instruments of favor and privilege and weapons of competitive oppression."

46 The Clayton Act, which Robinson-Patman amended, "is expressly designed with the view of correcting and forbidding a common and widespread unfair trade practice ... of great and powerful combinations ... to lower prices of their commodities, oftentimes below the cost of production in certain communities and sections where they had competition with the intent to destroy and make unprofitable the business of their competitors.' " FTC v. Anheuser-Busch, Inc., 363 U.S. 536, 543 n.6 (1960), quoting H.R. REP. No. 627, 63d. Cong., 2d. Sess. 8 (1914).

47 See Borden Co. v. FTC, 381 F.2d 175, 180-81 (1967), where the court pointed out the lack of necessary evidence for the FTC's case.

48 This is the view followed in the Second Circuit. Enterprise Indus., Inc. v. Texas Co., 240 F.2d 457 (2d Cir. 1956), cert. denied, 353 U.S. 965 (1957).

49 There was no such proof in Borden. Said the court: "[T] here is no evidence in the record that Borden refused to sell private label milk to any customer who specifically requested it." Borden Co. v. FTC, 381 F.2d 175, 178 (1967).

so In a two price scheme, refusal to deal equally with all customers in both lines 
for primary line injury, a seller following a predatory price cutting policy incurs temporary losses in the hope of eventual monopoly gains. Since he is unable to extract these gains so long as new competitors are free to enter the market, ${ }^{51}$ however, it seems highly unlikely that a seller will engage in such price cutting. Because it impedes judicial efficiency to presume the unlikely, the FTC should also carry the burden of proof in primary line injury cases. Proof burdens take on greater significance, however, when one considers the difficulties in establishing actual mispricing. In cases where there is virtually no evidence, the burden of proof may determine the outcome of the case. For consistency in the rule and in fairness to defendant, it is probably still wise to allocate the burden to the FTC. For example, where there is a sudden shift in demand, it seems fair to give the benefit of the doubt to businessmen who are setting prices in a market where proper pricing is a skillful guess at best. It is unlikely that any given seller is trying to misprice; and if he is, the proof will become available once demand has stabilized. Therefore, the burden of proof suggested by the Fifth Circuit in Borden is to be applauded; it neither assumes defendant's guilt nor emasculates the Robinson-Patman Act by laying an impossible task on the FTC.

An evaluation of the Fifth Circuit's remand Borden decision should also consider the proper definition of "competition," as that term is used in the Robinson-Patman Act. ${ }^{52}$ Rowe's definition of "competition" would protect only that competition which naturally occurs in the market absent monopoly. But if this were intended by Congress, the

might tend to show discriminatory motives rather than marketing motives. Borden does not resolve the issue whether it is necessary for a producer to make both products equally available. Since the FTC had not shown any instance of such a refusal, that question was not before the court. But the Fifth Circuit, 381 F.2d at 178, and the Supreme Court, 383 U.S. at 644 , both note the relevance of this kind of evidence.

51 McGee, Predatory Price Cutting: The Standard Oil (N.J.) Case, 1 J. LAw \& Econ. I37 (1958).

52 One interesting definition offered is that in Brooks, Injury to Competition under the Robinson-Patman Act, 109 U. PENN. L. REv. 777 (1963): "workable competition."

But in many ways that definition resolves itself into a "rule of thumb" test of economic competition. Conceptually, "workable competition" is composed of seven "rules of thumb" which provide structural and performance tests to judge the "competitiveness" of any market. While workable competition is useful as a shorthand method for the inexpert, its analysis is superficial. Consider, for example, the first part of the first rule: "There must be an appreciable number of sources of supply. . . ." This statement is readily understood by the layman if he does not look too deeply. Closer scrutiny might result in puzzled apprehension. How many is "appreciable"? Supply of what? Physically identical commodities, or near substitutes? Similarly, the explanation in Rule I that a trader must be able to "find a variety of other alternatives" and that the product be "substantially the same" is too general to be very helpful. An economist could illuminate the problem, of course, but only through detailed analysis. 
Robinson-Patman Act would have added nothing to previously existing antitrust law. ${ }^{53}$ On the other hand, implicit in the FTC's position is a desire to protect the competition which exists between established firms. While this view may be supported by judicial statements that the statute was intended to protect the small businessman from unfair prices and competition, ${ }^{54}$ the courts have also admonished that the Robinson-Patman Act should be read as "protecting competition, not competitors," 55 pointing out that competition is a battle in which some competitors must necessarily lose. ${ }^{56}$

Although Congress only intended to protect small businessmen from "unfair" market forces, ${ }^{57}$ the legislative history does not adequately indicate what class of practices were prohibited by the term "unfair." One possibility, as likely as any other, is that Congress hoped to protect those small businessmen who were capable of enduring in the competitive system absent "temporary" pricing policies by their suppliers; thus "competition" might mean the institutional framework which prevails in the long run in any given market. ${ }^{58}$ One practice that Congress

53 If monopoly or monopolizing is present, the Sherman Act should be sufficient protection. I5 U.S.C. $\$ \S 1,2$ (1964).

54 "Congress considered it to be an evil that a large buyer could secure a competitive advantage over a small buyer solely because of the large buyer's quantity purchasing ability." FTC v. Morton Salt Co., 334 U.S. 37, 43 (1948). The Robinson-Patman Act was passed due to congressional concern about the competitive effect "of mammoth purchasers, notably chain stores." FTC v. Anheuser-Busch, Inc., 363 U.S. 536, 543-44 (1960).

55 Anheuser-Busch, Inc. v. FTC, 289 F.2d 835, 840 (7th Cir. 1961); Atlas Building Prod. Co. v. Diamond Block \& Gravel Co., 269 F.2d 950, 954 (10th Gir. 1959), cert. denied, 363 U.S. 843. See also Crest Auto Supplies, Inc. v. Ero Mfg. Co., 360 F.2d 896 (7th Cir. 1966); Continental Baking Co. v. Utah Pie Co. 349 F.2d 122 (10th Cir. 1965), rev'd, 386 U.S. 685 (1967); Standard Motor Prod. Inc. v. FTC, 265 F.2d 674 (2d Cir.), cert. denied, 361 U.S. 826 (1959).

56 Atlas Building Prod. Co. v. Diamond Block \& Gravel Co., 269 F.2d 950, 954 (10th Cir. 1959); United States v. Standard Oil Co., 47 F.2d 288, 297 (E.D. Mo. 1931); Sinclair Ref. Co. v. FTC, 276 F, 686, 688 (7th Cir. 1921), aff'd, 261 U.S. 463 (1923); Balian Ice Cream Co. v. Arden Farms Co., 104 F. Supp. 796, 801 (S.D. Cal. 1952), affd, 231 F.2d 356 (9th Cir. 1955), cert. denied, 350 U.S. 991 (1956).

Consider, for example, the statement of the court in Atlas Bldg. Prod. Co. v. Diamond Block \& Gravel Co., 269 F.2d 950 (10th Cir. 1959), that antitrust legislation "is concerned with predatory price cutting which has the effect of eliminating or crippling a competitor. For, surely, there is no more effective means of lessening competition . . .."

57 The Act was designed to limit quantity differentials so that they would not "become instruments of favor, privilege and weapons of competitive oppression." H.R. REP. No. 2287, 74th Cong. 2d Sess. 7 (1936). In addition, the House majority report asserted: "[T] here is nothing in it [the Robinson-Patman Act] to penalize, shackle, or discourage efficiency or to reward inefficiency." Throughout the congressional debate, the arguments in favor of the statute were couched in terms of opposition to victimization, oppression, and cheating. See, e.g., 80 CoNG. REc. 8112 (1936); S. REP. No. 1502, 74th Cong., 2d Sess. 4 (1996).

58 See H.R. Rep. No. 2287, 74th Cong., 2d Sess. 17. (1936). See also. U.S. ATtORnEy GeNeral's National Committee to StUdy the ANTItrust LaWs, Report 1 (1955). 
hoped to eliminate was the temporary setting of prices below competitive levels by large chain stores in order to drive out smaller competitors. Another distasteful practice involved suppliers who, at the urging of large customers, charged higher prices to small customers, again in order to drive out these small businessmen. Neither of these two practices involved permanent price decreases in response to new market conditions; rather, the price changes which Congress forbade were temporary market dislocations.

The suggestion that "lessening competition" should include only temporary dislocations in long run market institutions also harmonizes the Robinson-Patman Act with the general policy of the antitrust laws. ${ }^{59}$ Efficient market institutions are thus protected by section 2(a) from temporary interference in the form of price discrimination.

Borden and prior cases defining "injury to competition" accord with the preceding interpretation. Refusing to adopt the Rowe "hands-off" position, the Supreme Court in Borden foreclosed the possibility that a mispriced private label good could be utilized to temporarily disrupt pricing, to injure certain select customers, or to temporarily drive out competitors. If the courts had adopted the FTC's view, however, mispricing would have been statutorily compelled in the form of equal prices for differently preferred goods, thus dislocating market institutions. Similarly, after a careful consideration of prior precedents, the Tenth Circuit in Anheuser-Busch ${ }^{60}$ concluded that no defendant had been found guilty of injuring primary line competition without proof of the malevolent use of market power or predatorial misconduct ${ }^{61}$ (the primary line form of mispricing). As for secondary line competition, the price differential in the Corn Products case, ${ }^{62}$ unlike the one

59 See, e.g., Automatic Canteen Co. v. FTC, 346 U.S. 61 (1953), rev'g, 194 F.2d 433 (7th Cir. 1952); United States v. Corn Prod. Ref. Co., 234 F. 964, 1012-13 (S.D.N.Y. 1916); United States v. Addyston Pipe \& Steel Co., 85 F. 271, 274 (6th Cir. 1898), aff'd, 175 U.S. 211 (1899).

While some precedent indicates that the purpose of the antitrust laws is to protect competitors from the need to adjust to market changes, United States v. Trans-Missouri Freight Ass'n 166 U.S. 290, 323 (1897), such a reading would result in considerable inefficiencies and the stagnation of market structures. To illustrate, useful innovations which might place established but inefficient firms at a competitive disadvantage would thus be proscribed. The better view seems to be that advanced by Judge Learned Fand:

The national will has not declared against elimination of competitors when they fail from their inherent industrial weakness. On the contrary, it has declared with great emphasis against any methods by which such weakness might be concealed....

United States v. Corn Prod. Ref. Co., 234 F. 964, 1015 (S.D.N.Y. 1916).

60 Anheuser-Busch, Inc. v. FTC, 289 F.2d 835 (7th Cir. 1961).

$61 I d$. at 841-42. This case also contains an excellent treatment of other relevant precedents.

62 Corn Prod. Ref. Co., v. FTC, 324 U.S. 726 (1945). 
in Borden, was an example of actual mispricing ${ }^{63}$ resulting from the imposition of a "phantom" freight charge unrelated to actual freight costs. This charge did not reflect any difference in consumer preferences; rather, the competitive situation between buyers required that all buyers receive an equally low price in order to stay in business. No buyer in Corn Products chose to pay the higher price, nor would they have so chosen as the customers did in Borden. The case law thus supports the proposition that mispricing must be present in order for there to be a "lessening of competition."

\section{Conclusion}

The background surrounding the enactment of the RobinsonPatman Act suggests that Congress may have intended to protect competitive institutions from temporary dislocations. The case law also supports this interpretation. Rather than being such a temporary dislocating factor, private label distribution represents the permanent, long term profit maximizing policy of a firm producing a differentiated product. So long as mispricing is not present, efficient market institutions are not disrupted by private label distribution. Therefore, the Fifth Circuit's refusal to proscribe this practice is both economically and legally sound.

63 Similarly, in FTC v. Morton Salt Co., 334 U.S. 37 (1948), mispricing was present, since the price differential was not justified by either a cost or a consumer preference differential. 